\title{
Phosphorous Use Efficiency of Safflower and Sunflower Grown in Different Soils
}

\author{
Jehad Abbadi* \\ Biology Department, College of Science and Technology, Al-Quds University, Jerusalem, Palestine \\ *Corresponding author: jihadabbadi@yahoo.com
}

\begin{abstract}
The use of nutrient efficient alternative crops is a possible strategy of sustainable land use. Plant species vary in their phosphorous $(\mathrm{P})$ use efficiency under suboptimal $\mathrm{P}$ supplies in different soils by using different strategies. Cultivating $\mathrm{P}$ efficient species to improve yields may be possible if $\mathrm{P}$ efficiency mechanisms are elucidated. Therefore $\mathrm{P}$ use efficiency of the alternative oil crops safflower and sunflower was studied under semicontrolled conditions in sandy and loamy soils using three P supplies. Both species responded strongly to increasing $\mathrm{P}$ supplies in both soils and performed better in loamy soil. In both soils, both species contained similar P concentrations in shoots at low P supplies, but safflower accumulated less $\mathrm{P}$ amounts in shoots than sunflower at all P levels. Sunflower had less external P requirements than safflower in both soils. Safflower had higher efficiency ratio than sunflower at low P supply in sandy soil, and less values in loamy soils. Safflower had lower utilization index than sunflower in both soils at all P levels. Safflower recovered less external P (added P, extractable-P, soil solution-P) than sunflower in both soils. The P use efficiency of crops is based on different competitive components. Neither safflower nor sunflower showed a combination of high values of all P use efficiency components in both soils at all P levels, but safflower was inferior to sunflower in most studied traits. Therefore safflower cannot be considered a low input species as compared to sunflower in terms of P uptake and utilization efficiency.
\end{abstract}

Keywords: sustainable agriculture, phosphorous, utilization efficiency, alternative crops, carthamus tinctorius, helianthus annuus, safflower

Cite This Article: Jehad Abbadi, "Phosphorous Use Efficiency of Safflower and Sunflower Grown in Different Soils.” World Journal of Agricultural Research, vol. 5, no. 4 (2017): 212-220. doi: 10.12691/wjar-5-4-3.

\section{Introduction}

Phosphorus (P) is an essential inorganic nutrients for all living organisms, required as a structural component in nucleic acids and phospholipids, as an element in intermediates of carbon metabolism, and to allow (in) activation of a wide range of enzymes [1]. After nitrogen, $\mathrm{P}$ is quantitatively the most important inorganic nutrients for plant growth that limits primary productivity in natural and cropping systems, unless supplied as fertilizer [2]. Although many soils have large reserves of total $\mathrm{P}$, only a small fraction is immediately available making many agricultural areas deficient with $\mathrm{P}$ [3]. Low P availability results from its fixation as calcium apatite, utilization by organisms to form organic $\mathrm{P}$, and by sorption onto iron and aluminium [4].

As a result of the intensification of agriculture and introduction of high yielding varieties, the soils of many regions are getting depleted in reserve $\mathrm{P}$ at a faster rate, therefore $\mathrm{P}$ deficiency is becoming one of the major constraints to crop production [3]. Although, in view of limited $\mathrm{P}$ resources and serious environmental and economic consequences [3,5], a considerate use of $\mathrm{P}$ is mandatory to correct nutrient deficiencies to fulfill the requirements of modern cultivars [6]. But in developing countries, where the proportion of less fertile soil is particularly high, it may be difficult to fulfill the nutritional requirements of high yielding crops [1].

Plant species and even cultivars within a species differ in their nutrient use efficiency (NUE) [7,8,9,10,11]. Plant species and cultivars differ in their ability to grow or yield well at suboptimal P supply $[12,13,14]$. Therefore, one of the possible strategies of sustainable land use, which enables maximum output with minimum input, sustains resources and conserves the environment, could be the use of nutrient efficient plant species [15]. Accordingly, species which are able to make use of the normally not readily available nutrients such as $\mathrm{P}$ could have a significant agronomic importance [16]. However, cultivating nutrient efficient species or cultivars to improve yields or developing genotypes that are more P-efficient may be possible if $\mathrm{P}$ efficiency mechanisms are elucidated $[7,14]$. Definitions of NUE vary greatly [17] and in some cases, may be misleading in terms of identifying the mechanisms for the nutrient use efficiency [6]. Therefore, NUE is generally defined as the ability of species or cultivars to grow and yield better in a substrate containing suboptimal nutrient supply that would limit the production of other standard lines [18]. Other definitions of NUE, is the production of dry matter or harvestable products per unit of nutrient applied, and referred to as agronomic efficiency [19]. In like manner, the external nutrient requirement refers to the amount of nutrient in the media required to achieve a given percentage of maximum yield 
[20]. Additionally, the yield response per unit of added nutrient has also been used as a measure of NUE [13,21]. The ability of cultivars to tolerate low nutrient supply may be due to either high nutrient uptake ability at low nutrient concentrations and/or more efficient use of a nutrient for more yield production [6]. Therefore, NUE may be broken down mechanistically into uptake efficiency and utilization efficiency. In other words, overall NUE in plants is a function of capacity of soils to supply adequate levels of nutrients, and the ability of plants to acquire these nutrients, transport them in roots and shoots and remobilise them to other parts of the plant, involving various soil and plant mechanisms and processes that contribute to genetic variability in efficiency of uptake and utilization of nutrients [22].

The use of alternative oil crops that differ in their response to $\mathrm{P}$ supply is a possibility to meet the increasing global demand for vegetable oil, and may be possible if $\mathrm{P}$ efficiency mechanisms are characterized. For instance, safflower (Carthamus tinctorius L.) and sunflower (Helianthus annuus L.), both belonging to the same family (Asteraceae), are important oil crops in tropical areas. Safflower was hypothized as a low input cultivar [23], and this was supported by recent work concerning the agronomic efficiency of $\mathrm{N}$ and $\mathrm{K}$ when it was compared with sunflower [9-11], but safflower failed to be low input cultivar compared with sunflower in terms of $\mathrm{P}[12,14]$. The mechanisms that outline the $\mathrm{P}$ efficiency of safflower as compared to sunflower grown in different soils were not investigated. Therefore, the objective of this investigation was to study the efficiency mechanisms of phosphorous utilization of safflower and sunflower in pot experiment using two low-P status soil types (sandy and loamy) in greenhouse conditions.

\section{Methodology}

\subsection{Experimental Design}

A pot experiment was conducted to evaluate P utilization efficiency of safflower (Carthamus tinctorius L., variety 'Sabina') and sunflower (Helianthus annuus L., variety 'Peredovick E'), grown in two soil types (loamy and sandy), using three levels of $\mathrm{P}$ supplies. The experiment was conducted in a Semi-controlled climatic conditions in a greenhouse in the period between June to September 2012. Before conducting the experiment, field-moist soil samples were sieved to 2-mm particle size, from which, subsamples of soil were air dried and were analyzed for extractable $\mathrm{P}$, exchangeable $\mathrm{K}, \mathrm{Mg}$, and $\mathrm{pH}$. Initially, the sandy soil (pH 5.6 by water extraction) contained $26 \mathrm{mg}$ $\mathrm{kg}^{-1}$ calcium acetate lactate (CAL)- extractable P, $22 \mathrm{mg}$ $\mathrm{kg}^{-1}$ CAL-exchangeable $\mathrm{K}$, and $28 \mathrm{mg} \mathrm{kg}^{-1} \mathrm{NH}_{4}$-acetate exchangeable $\mathrm{Mg}$. The loamy soil ( $\mathrm{pH} 7.0$ by water extraction) contained $16.5 \mathrm{mg} \mathrm{kg}^{-1}$ CAL-extractable P, 28 mg kg-1 CAL-exchangeable $\mathrm{K}$, and $141 \mathrm{mg} \mathrm{kg}^{-1} \mathrm{NH}_{4^{-}}$ acetate exchangeable Mg.

Mitscherlich pots $(6 \mathrm{~L})$ were filled with $3 \mathrm{~kg}$ sand $(0$ mg kg-1 CAL-extractable P, $3 \mathrm{mg} \mathrm{kg}^{-1}$ CAL-exchangeable $\mathrm{K}$, and $1.8 \mathrm{mg} \mathrm{kg}^{-1} \mathrm{NH}_{4}$-acetate exchangeable $\mathrm{Mg}, \mathrm{pH}$ in water was 7.3) and $3 \mathrm{Kg}$ either sandy or loamy soil. Three $\mathrm{P}$ levels $\left(0,0.2\right.$, and $1.0 \mathrm{~g} \mathrm{P}$ pot $\left.^{-1}\right)$ were added as Ca
$\left(\mathrm{H}_{2} \mathrm{PO}_{4}\right)_{2} \cdot \mathrm{H}_{2} \mathrm{O}$, resulting in solution $\mathrm{P}\left(\mathrm{mg} \mathrm{P} \mathrm{L}^{-1}\right.$ soil solution) content of $0.22,0.61,8.21$ for sandy soil and $0.00,0.15,45.67$ for loamy soil in consecutive added $\mathrm{P}$ levels. The extractable $\mathrm{P}$ content (mg $\mathrm{P} \mathrm{Kg} \mathrm{soil}{ }^{-1}$ ) of the soil after adding external $\mathrm{P}$ were 25.0, 50.8, 229.5 for sandy soil and 35.4, 54.3, 263.0 for loamy soil in respective $\mathrm{P}$ supplies. Other nutrients added per pot were 2 g N (as $\mathrm{NH}_{4} \mathrm{NO}_{3}$ ), 0.8g $\mathrm{Mg}$ (as $\mathrm{MgSO}_{4}$ ), $3 g \mathrm{~K}$ (as $\mathrm{K}_{2} \mathrm{SO}_{4}$ ). Micronutrients were added in adequate amount for both species in both soil types (mg pot ${ }^{-1}: 17.5 \mathrm{~B}, 2.5 \mathrm{Mo}, 8 \mathrm{Cu}$, $50 \mathrm{Mn}$, and $40 \mathrm{Zn}$ ). Three safflower or two sunflower plants were planted in each pot (because sunflower is larger than safflower). The treatments were replicated four times. The plants were watered daily to nearly a volumetric soil water content of 35\%. The experiment was conducted as a completely randomized design.

\subsection{Harvesting and Analytical Procedures}

The plants were harvested after 42 and 56 days from sowing for both species in both soil types. One pot of each treatment was harvested in the first harvest and the rest three pots of each treatment were harvested in the second harvest. Harvested plants were separated to stems and leaves. Stems and leaves were measured for dry weight, then were analyzed for their P contents.

\section{Shoot Measurements and $P$ and Analysis}

At harvest, the dry weight of plant parts were determined after drying at $70^{\circ} \mathrm{C}$ till constant weight. Dried plant materials were grinded to pass a $1.5 \mathrm{~mm}$ sieve, of which, after thorough mixing, a sub-sample of $5 \mathrm{~g}$ was ball-milled to a fine powder. The plant samples were prepared for $\mathrm{P}$ analysis using wet microwave digestion using concentrated tri acid mixture $\left(\mathrm{HNO}_{3}, \mathrm{HClO}_{4}\right.$, and $\mathrm{H}_{2} \mathrm{SO}_{4}$ with a volumetric ratio of $8: 2: 1)$. Total $\mathrm{P}$ of the plant material digest was measured using Ammonium-VanadateMolybdate colorimetric method [24].

\section{Measurement of Soil Solution P Concentration, Extractable $\mathbf{P}$ Concentration and $\mathbf{p H}$}

The column displacement method [25] was used to collect the unaltered composition of soil solution $\mathrm{P}$ concentrations, in which a sample of moist soil equivalent to $350 \mathrm{~g}$ was packed into a plastic column with a pore in its bottom. Filter paper was placed in the bottom of each soil column to avoid soil particles losses during the collection. The samples were allowed to equilibrate for 24h; then, deionized water was pumped to each column at a rate of $4 \mathrm{ml} \mathrm{h}^{-1}$ until the soils reached field capacity water content. The displaced solution was collected tell $25 \mathrm{ml}$ to insure not to collect diluted solution, and then filtered through a $0.20 \mu \mathrm{m}$ filter. The solutions were analyzed for P by colorimetric method [24]. Soil solution concentration was measured immediately at the time of each harvest.

To determine solid phase (extractable) P, a $10 \mathrm{~g}$ subsample of soil was air dried then extracted with calcium acetate lactate (CAL) method [26]. To determine solid phase (extractable) $\mathrm{Mg}$, an air dried $10 \mathrm{~g}$ subsample of soil from each pot was extracted using $\mathrm{NH}_{4}$-acetate extraction. Phosphorous concentration in the extracts was 
determined also using colorimetric method [24]. The $\mathrm{pH}$ was measured using water extraction.

\subsection{Calculating Efficiency Indicators}

Different measures of nutrient efficiency were determined at different $\mathrm{P}$ levels. $\mathrm{P}$ accumulated ( $\mathrm{mg} \mathrm{P}$ pot $^{-1}$ ) in plant parts were calculated by the multiplication of plant parts weight in g (leaves, stems) with plant tissue $\mathrm{P}$ concentration multiplied by 100 . Total mg $\mathrm{P}$ accumulated per pot was calculated as the sum of the mg $\mathrm{P}$ accumulated in each plant part per pot. $\mathrm{P}$ concentration $\left[\mathrm{mg}\right.$ nutrient $\mathrm{g}^{-1}$ dry matter (DM)] in the plant was obtained from dividing the total mg $\mathrm{P}$ accumulated per pot by the total dry mater of the plant per pot (g) divided by 10 . P recovery (uptake efficiency) was calculated by dividing total $\mathrm{P}$ accumulated per pot ( $\mathrm{g} \mathrm{P}_{\mathrm{P}} \mathrm{t}^{-1}$ ) by external $\mathrm{P}$ supply interpreted as added $\mathrm{P}$ supply, soil solution-P, and CAL-P ( $\mathrm{g} \mathrm{pot}^{-1}$ ) [27]. External $\mathrm{P}$ requirement termed as agronomic utilization efficiency [g P required ( $\mathrm{g} \mathrm{DM}$ produced) ${ }^{-1}$ ] at each $\mathrm{P}$ level was obtained by dividing the $\mathrm{P}$ supply $\left(\mathrm{g} \mathrm{P}_{\mathrm{pot}}{ }^{-1}\right.$ interpreted as $\mathrm{P}$ supply, soil solution $\mathrm{P}$ or CAL extractable $\mathrm{P})$ by $\mathrm{DM}$ yield at that $\mathrm{P}$ level. $\mathrm{P}$ efficiency ratio (PER) was calculated as total plant dry mass $\left(\mathrm{g} \mathrm{pot}^{-1}\right)$ divided by total $\mathrm{P}$ accumulation (g P pot ${ }^{-1}$ ) [28]. Nutrient utilization index [29] was calculated by dividing DM yield (g pot ${ }^{-1}$ ) by nutrient content in whole plant [g P (g DM) $)^{-1}$.

\subsection{Statistical Analysis}

All statistical analyses were carried out using SAS (SAS Institute Inc., Cary, USA, Release 8.02, 2001). Comparisons of means between different treatments were carried out using the GLM procedure considering a fully randomized design. With multiple t-test, the Bonferoni procedure was employed in order to maintain an experiment-wise $\alpha$ of $5 \%$.

\section{Results}

\subsection{Growth and Morphology}

The dry matter (DM) weight of both species responded strongly to increasing $\mathrm{P}$ supply in both soils (Figure 1). DM production in both crops performed better when grown in loamy as compared to sandy soils, except at 0 added P supply for sunflower. Under low P supplies, typical $\mathrm{P}$ deficiency symptoms characterized by smaller darker leaves, and thinner stem diameter were observed in both species in both soil types.

\section{2. $P$ accumulation in Dry Matter}

Both crops contained similar P contents (mg P 100 $\mathrm{mg} \mathrm{DM}^{-1}$ ) in shoots when grown at respective 0 and $0.2 \mathrm{~g} \mathrm{P}^{\mathrm{P}}$ pot $^{-1}$ in both soils, while at high P supply, safflower had significantly lower P content than that of sunflower in both soil types (Figure 2). Both species concentrated significant higher values when grown in sandy soils as compared with loamy soil at 0 added $\mathrm{P}$ supplies. At $0.2 \mathrm{~g} \mathrm{P}$ supply, $\mathrm{P}$ content was similar in safflower among soil types, while that of sunflower was higher in loamy soil as compared to sandy soil. At high P supply, shoots of safflower concentrated more $\mathrm{P}$ in loamy soil while the opposite was recorded for sunflower.
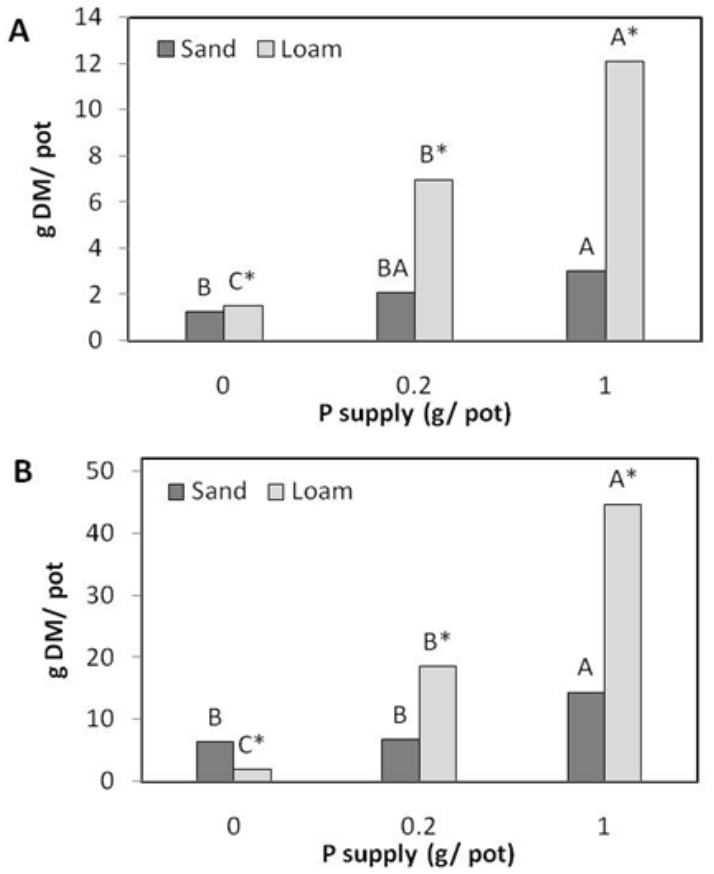

Figure 1. Effect of P supply on dry matter $\left(\mathrm{g} \mathrm{pot}^{-1}\right)$ of safflower (A) and sunflower (B). For a given species and a given soil type, means within each column followed by the same letter are not significantly different, * indicates significant difference for a given plant species and a given $\mathrm{P}$ level within soil types. $\mathrm{P}<0.05, \mathrm{n}=3$
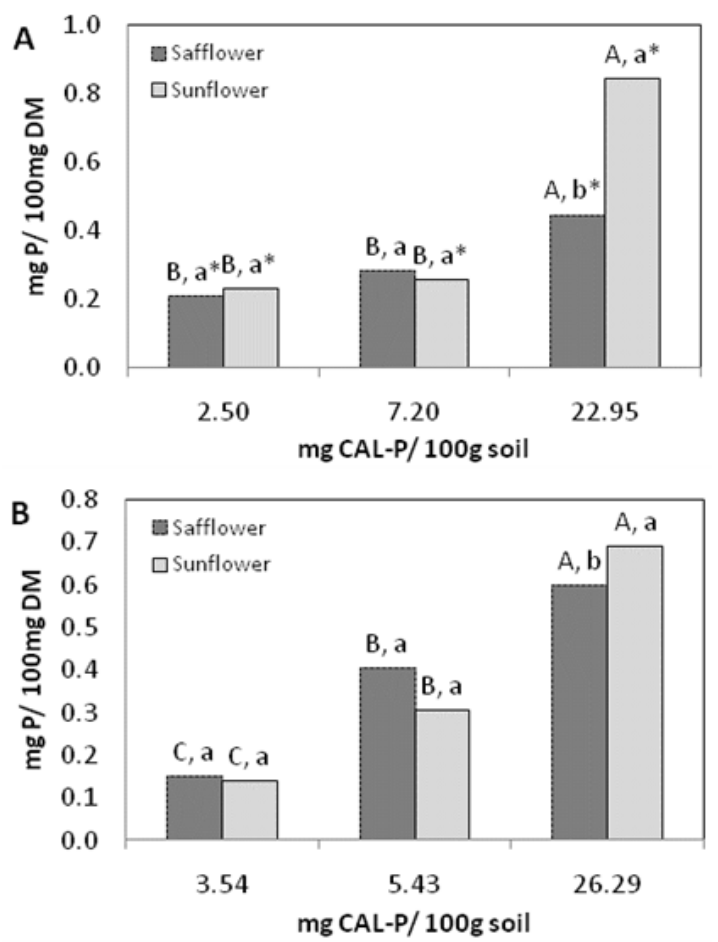

Figure 2. Effect of $P$ supply on $P$ concentration (mg P $100 \mathrm{mg} \mathrm{DM}^{-1}$ ) of safflower and sunflower in sandy soil (A) and loamy soil (B). For a given species and a given soil type, means within each column followed by the same capital letter are not significantly different, means in the same soil type and the same P level and different plant species followed by the same small letter are not significantly different, * indicates significant difference for a given plant species and a given $\mathrm{P}$ level within soil types. $\mathrm{P}<0.05, \mathrm{n}=3$ 

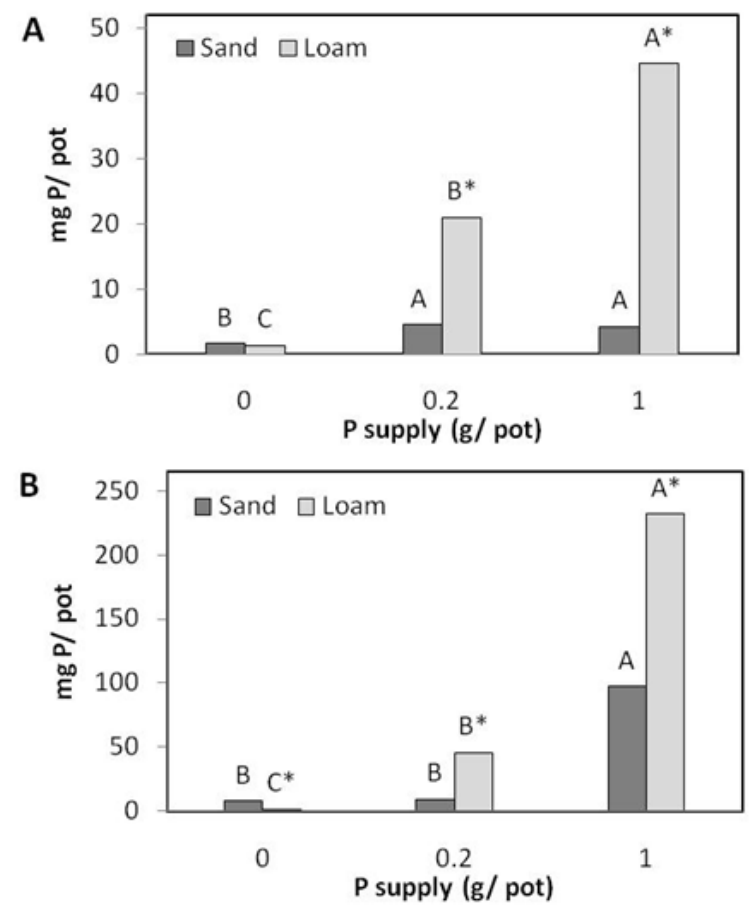

Figure 3. Effect of $\mathrm{P}$ supply on $\mathrm{P}$ accumulation between harvests (mg P pot ${ }^{-1}$ ) for safflower (A) and sunflower (B). For a given species and a given soil type, means within each column followed by the same letter are not significantly different, * indicates significant difference for a given plant species and a given $\mathrm{P}$ level within soil types. $\mathrm{P}<0.05, \mathrm{n}=3$

Increasing amounts of $\mathrm{P}\left(\mathrm{mg} \mathrm{pot}^{-1}\right)$ was accumulated in shoots of both species with increasing external $\mathrm{P}$ supply (mg CAL-P 100g soil ${ }^{-1}$ ) during the studied growth period. To avoid differences between the two species in terms of the adaptation to the growing media at the beginning and differences in size of sunflower and safflower, data was calculated between the two harvests. The total accumulated $\mathrm{P}$ in shoots of both crops increased significantly between the two harvests when $\mathrm{P}$ supply increased in both soils (Figure 3). The total P accumulation was significantly lower in safflower as compared to sunflower at all respective P supplies in both soil types as safflower is smaller than sunflower. In both plant species, plants grown in loamy soil accumulated significantly higher $\mathrm{P}$ in shoots as compared to those grown in sandy soil in all respective $\mathrm{P}$ levels except at low P supply for safflower.

\section{3. $P$ use efficiency}

\subsubsection{P utilization Efficiency}

The P-efficiency ratio (PER) is a frequently used utilization efficiency indicator, defined as the biomass production per unit $\mathrm{P}$ accumulated in DM (Figure 4A, B). PER of both plant species increased significantly with decreasing phosphorous supply in both soil types. In sandy soil, safflower was found more efficient (higher PER) than sunflower under low and high P supplies, while the opposite was observed under intermediate P supply. In loamy soil, safflower was superior as compared to sunflower under high P supply only, while both species showed the same efficiency under 0 and $0.2 \mathrm{~g}$ external P pot ${ }^{-1}$.
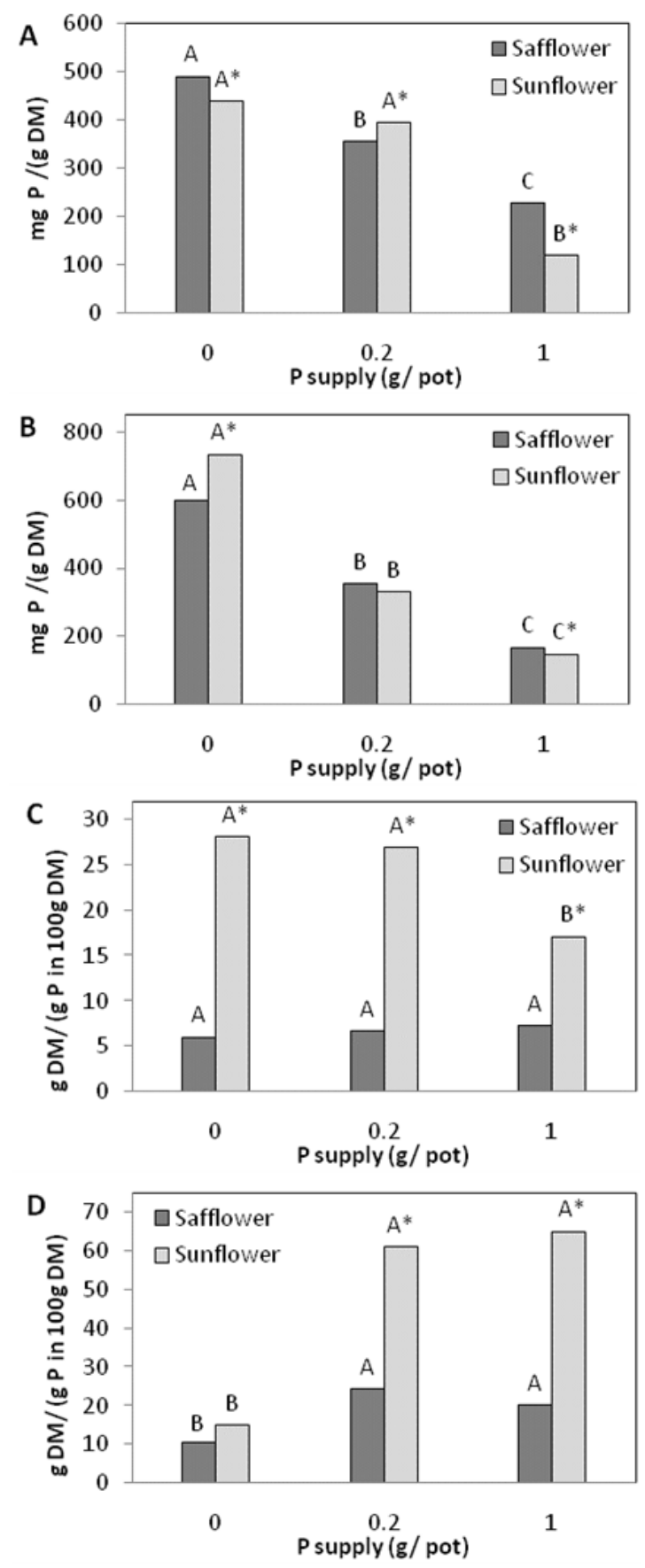

Figure 4. Effect of P supply on PER (mg P in DM/ g DM) (A and B), PUI (g DM/ (g P 100g DM-1) (C and D) for safflower and sunflower in sandy (A, C) and loamy (B, D) soil. For a given species and a given soil type, means within each column followed by the same letter are not significantly different. * indicates significant difference between the two columns in each figure at the same $\mathrm{P}$ level. $\mathrm{P}<0.05, \mathrm{n}=3$

In contrary to the PER, the utilization index (UI) is based on the yield (dry matter) per unit nutrient concentration in dry matter (Fig. 4C, D). In sandy soil, safflower maintained constant UI at different P supplies, but sunflower UI decreased at the highest P supply. In loamy soil both species reduced UI under 0 added $\mathrm{P}$ supply. Safflower had the same UI in both soil types under severe $\mathrm{P}$ deficiency, while they were less efficient in sandy soils under 0.2 and $1.0 \mathrm{~g} \mathrm{P} \mathrm{pot}^{-1}$. UI of sunflower was higher in sandy soil as compared to that in loamy soil at low P supply, while the opposite was observed at higher 
$\mathrm{P}$ supplies $\left(0.2\right.$ and $\left.1.0 \mathrm{~g} \mathrm{P} \mathrm{pot}^{-1}\right)$. Safflower was inferior to sunflower in terms of UI in both soils at all respective supplies of $P$.

\subsubsection{External (agronomic) $P$ requirement}

The external or agronomic $\mathrm{P}$ requirement (Table 1), is defined as the amount of $\mathrm{P}$ in the substrate required to produce a given relative or absolute yield $[9,19,20]$. The higher values indicate less efficiency. External P requirement in all mentioned means of external $\mathrm{P}$ ( $\mathrm{P}$ supply, CAL-P, and soil solution P) for both species and both soil types increased significantly with increasing $P$ supplies. Agronomic requirements in all mentioned terms of $\mathrm{P}$ supply were significantly higher for safflower as compared to sunflower at all respective $\mathrm{P}$ supplies, except for soil solution- $\mathrm{P}$ at 0 added $\mathrm{P}$ supplies, where both species were statistically similar. All interpretations of the external P requirements showed that both species had significantly more values in sandy soils as compared to loamy soils at all respective P supplies except for CAL-P in safflower at very low $\mathrm{P}$ level were the values among both soil types didn't change significantly, and also in the same indicator for sunflower at low P supply where the opposite was observed.

\subsection{3. $P$ recovery}

$\mathrm{P}$ recovery in terms of added $\mathrm{P}$ supplies, decreased with increasing $\mathrm{P}$ supply in safflower in both soils, while it increased with increasing $P$ supply in sunflower in sandy soil and didn't changed significantly in loamy soil
(Table 2). Recovery of P in terms of CAL-P decreased significantly in sandy soil in both species, while the opposite was observed in loamy soil. Both species recovered decreasing amounts of soil solution $\mathrm{P}$ with increasing $\mathrm{P}$ supply in both soil types under study. The recovery of $\mathrm{P}$ was significantly lower for safflower as compared to sunflower at all respective P supplies for all means of external P nutrition (added P supply, CAL-P, and soil solution $\mathrm{P}$ ) in both soil types. Values of $\mathrm{P}$ recovery in terms of added $\mathrm{P}$ supplies and external soil solution-P were significantly lower in sandy soils as compared to loamy soil in all respective $\mathrm{P}$ levels for both species. While in terms of CAL-P, phosphorous recovery was higher in sandy soils for both species at very low $\mathrm{P}$ level only and the opposite was observed at higher $\mathrm{P}$ levels. In terms of $\mathrm{P}$ supply, Table 1 reveals that only small fraction of added $\mathrm{P}$ is recovered by both species in both soils at different $\mathrm{P}$ supplies with a minimum of around $1 \%$ and a maximum around $31 \%$. The P recovery from sandy soil was significantly less than the percentage recovery from loamy soil at both $\mathrm{P}$ levels. The fraction recovered by plants from the readily extractable $\mathrm{P}$ ranged between around $1 \%$ to maximum $20 \%$ of the potentially soilsurface absorbed $\mathrm{P}$ which is available with high accessibility because it is readily exchangeable with the soil solution. Soil solution $\mathrm{P}$ is immediately available and accessible in solution. The plants depleted this fraction many times during the experiment (6 to 228 times). The required number of depletion turns from soil solution was less in sandy soil as compared to loamy soils at all P levels in both species.

Table 1. Effect of $P$ supply on external $P$ requirement (g external $P$ to produce $1 \mathrm{~kg}$ of $D M$ ) for safflower and sunflower. For a given species and a given soil type, means within each column followed by the same capital letter are not significantly different, means in the same soil type and the same $\mathbf{P}$ level and different plant species followed by the same small letter are not significantly different, * indicates significant difference for a given plant species and a given $P$ level within soil types. $P<0.05, n=3$

\begin{tabular}{|c|c|c|c|c|c|c|}
\hline \multirow{2}{*}{$\begin{array}{l}\text { K supply } \\
\left(\mathrm{g} \mathrm{pot}^{-1}\right)\end{array}$} & \multicolumn{2}{|c|}{ g added $\mathrm{P} / 1 \mathrm{~kg} \mathrm{DM}$} & \multicolumn{2}{|c|}{ g CAL- P/ 1kg DM } & \multicolumn{2}{|c|}{ g soil solution $\mathrm{P} / 1 \mathrm{~kg} \mathrm{DM}$} \\
\hline & Sand & Loam & Sand & Loam & Sand & Loam \\
\hline \multicolumn{7}{|c|}{ Safflower } \\
\hline 0 & - & - & $153.48 \mathrm{~B}, \mathrm{a}$ & $145.32 \mathrm{~A}, \mathrm{a}$ & $0.44 \mathrm{~B}, \mathrm{a} *$ & $0.007 \mathrm{~B}, \mathrm{a}$ \\
\hline 0.2 & $100.27 \mathrm{~B}, \mathrm{a}$ * & $30.10 \mathrm{~B}, \mathrm{a}$ & $216.63 \mathrm{BA}, \mathrm{a} *$ & 49.04 B, a & $0.61 \mathrm{~B}, \mathrm{a} *$ & $0.068 \mathrm{~B}, \mathrm{a}$ \\
\hline 1.0 & $356.47 \mathrm{~A}, \mathrm{a}$ * & $83.60 \mathrm{~A}, \mathrm{a}$ & $490.87 \mathrm{~A}, \mathrm{a} *$ & $131.80 \mathrm{~A}, \mathrm{a}$ & $5.85 \mathrm{~A}, \mathrm{a} *$ & $2.544 \mathrm{~A}, \mathrm{a}$ \\
\hline \multicolumn{7}{|c|}{ Sunflower } \\
\hline 0 & - & - & $23.80 \mathrm{C}, \mathrm{b}$ * & 106.24 A, b & $0.07 \mathrm{~B}, \mathrm{~b} *$ & $0.005 \mathrm{C}$, a \\
\hline 0.2 & $30.10 \mathrm{~B}, \mathrm{~b} *$ & $11.03 \mathrm{~B}, \mathrm{~b}$ & $65.01 \mathrm{~B}, \mathrm{~b} *$ & $18.00 \mathrm{~B}, \mathrm{~b}$ & $0.18 \mathrm{~B}, \mathrm{~b} *$ & $0.025 \mathrm{~B}, \mathrm{~b}$ \\
\hline 1.0 & $70.87 \mathrm{~A}, \mathrm{~b} *$ & $22.43 \mathrm{~A}, \mathrm{~b}$ & $97.55 \mathrm{~A}, \mathrm{~b}$ * & 35.36 B, b & $1.16 \mathrm{~A}, \mathrm{~b} *$ & $0.683 \mathrm{~A}, \mathrm{~b}$ \\
\hline
\end{tabular}

Table 2. Effect of $P$ supply on $P$ recovery $\left(\mathrm{mg} \mathrm{P} \mathrm{TDW}^{-1} / \mathrm{mg} \mathrm{P}\right.$ supply)*100, $\left(\mathrm{mg} \mathrm{P} \mathrm{TDW}^{-1} / \mathrm{CAL} \mathrm{mg} \mathrm{P}^{*} \mathbf{1 0 0}\right.$, (mg P TDW ${ }^{-1} /$ Soil solution mg $P$ )*100 for safflower and sunflower. For a given species and a given soil type, means within each column followed by the same capital letter are not significantly different, means in the same soil type and the same $P$ level and different plant species followed by the same small letter are not significantly different, * indicates significant difference for a given plant species and a given $P$ level within soil types. $P<0.05, n=3$

\begin{tabular}{|c|c|c|c|c|c|c|}
\hline \multirow{2}{*}{$\begin{array}{l}\text { K supply } \\
\left(\mathrm{g} \mathrm{pot}^{-1}\right)\end{array}$} & \multicolumn{2}{|c|}{ (mg P TDW ${ }^{-1} /$ mg P supply) *100 } & \multicolumn{2}{|c|}{$\left.\left(\mathrm{mg} \mathrm{P} \mathrm{TDW}^{-1} / \mathrm{CAL} \mathrm{mg} \mathrm{P}\right) * 100\right)$} & \multicolumn{2}{|c|}{$\left(\mathrm{mg} \mathrm{P} \mathrm{TDW}^{-1} /\right.$ Soil solution mg P) *100) } \\
\hline & Sand & Loam & Sand & Loam & Sand & Loam \\
\hline \multicolumn{7}{|c|}{ Safflower } \\
\hline 0 & - & - & $1.73 \mathrm{~A}, \mathrm{~b} *$ & $1.07 \mathrm{~B}, \mathrm{~b}$ & $603.2 \mathrm{~A}, \mathrm{~b} *$ & 22821 A, b \\
\hline 0.2 & $2.92 \mathrm{~A}, \mathrm{~b} *$ & $10.07 \mathrm{~A}, \mathrm{~b}$ & $1.35 \mathrm{BA}, \mathrm{b} *$ & $4.58 \mathrm{~A}, \mathrm{~b}$ & $481.5 \mathrm{~B}, \mathrm{~b} *$ & 4474 B, b \\
\hline 1.0 & $1.37 \mathrm{~B}, \mathrm{~b} *$ & 7.22 B, b & $0.99 \mathrm{~B}, \mathrm{~b} *$ & $6.18 \mathrm{~A}, \mathrm{~b}$ & $83.4 \mathrm{C}, \mathrm{b}$ * & 237 C, b \\
\hline \multicolumn{7}{|c|}{ Sunflower } \\
\hline 0 & - & - & $9.64 \mathrm{~A}, \mathrm{a} *$ & $1.30 \mathrm{~B}, \mathrm{a}$ & 3361.9 A, a * & 27593 A, a \\
\hline 0.2 & $8.56 \mathrm{~B}, \mathrm{a} *$ & $28.09 \mathrm{~A}, \mathrm{a}$ & $8.83 \mathrm{~A}, \mathrm{a} *$ & $17.25 \mathrm{~A}, \mathrm{a}$ & 1410.6 B, a * & 12486 B, a \\
\hline 1.0 & $12.16 \mathrm{~A}, \mathrm{a} *$ & $30.75 \mathrm{~A}, \mathrm{a}$ & $3.96 \mathrm{~B}, \mathrm{a} *$ & $19.49 \mathrm{~A}, \mathrm{a}$ & $740.8 \mathrm{C}, \mathrm{a} *$ & $1010 \mathrm{C}, \mathrm{a}$ \\
\hline
\end{tabular}




\section{Discussion}

\subsection{Growth and Morphology}

Biomass is an important trait in growth analysis [30], where its repeated measurements are the basis for the calculations of net primary production of plants [31,32], and thus is considered a good indicator of economic yield $[33,34]$. Therefore differences among crop species for relative shoot dry matter production indicated that this trait can be used as reliable parameter for screening efficient cultivars $[35,36]$. Because growth of both species increased dramatically with increasing $\mathrm{P}$ supplies under study, the highest P supply was considered as the 100\% relative DM produced by both species in both soil types. In sandy soil, both species were similar in relative DM production under 0 added $\mathrm{P}(40.7 \%$ and $44.1 \%$ for safflower and sunflower respectively), while at 0.2 added $\mathrm{P}$ pot $^{-1}$, safflower has significant superiority over sunflower in relative DM production (68.2\% for safflower vs. $47.0 \%$ for sunflower). In clay soil, safflower produced significantly higher relative DM production as compared to sunflower at both 0 and $0.2 \mathrm{~g} \mathrm{P}$ supply pot ${ }^{-1}$ (12.5 and 57.8\% for safflower vs. 4.5 and $18.5 \%$ for sunflower under 0 and $0.2 \mathrm{~g}$ added $\mathrm{P}$ respectively). In agreement with our findings (Figure 1), P nutrition was reported to have a positive influence on dry matter production in sunflower [12,14]. Unlike other reports, we found that sunflower is more sensitive to $\mathrm{P}$ deficiency than safflower in terms of relative dry matter accumulation in loam soil under the very low and intermediate $\mathrm{P}$ supplies, and in sandy soil at intermediate P supply [12,37].

\subsection{P Accumulation in Dry Matter}

Phosphorus efficient crops, adapted to low P-supplying soils, are often characterized by low P requirements [38]. Crop species can grow normally with low tissue $\mathrm{P}$ concentrations due to efficient use of $\mathrm{P}$ among the major biochemical fractions (soluble-P, lipid-P, and residue-P) and were found to be more tolerant to low $\mathrm{P}$ conditions than that which exhibited high $\mathrm{P}$ concentrations in their tissues [39]. Both species under investigation had the same internal $\mathrm{P}$ concentration in their shoots at low and intermediate P supplies (Figure 2), but this figure was less in safflower as compared to sunflower when the crops were grown in high added $\mathrm{P}$ soil. This could be explained by the high demand of sunflower for $\mathrm{P}$ as compared to safflower. In the other hand, the productive efficiency of $\mathrm{P}$ for grain or seed is higher at early growth stages than at later stages because $\mathrm{P}$ is needed for tillering or branching. If sufficient $\mathrm{P}$ is absorbed at early growth stages, it will be redistributed to other growing organs [1,39]. More root growth and more distribution of $\mathrm{P}$ to the roots [40] are among reasons that reduce $\mathrm{P}$ concentration and accumulation in vegetative parts and make plants retain more $\mathrm{P}$ in their roots than shoots [41] in plants under P-starvation conditions.

Both species in both soil types accumulated increasing $\mathrm{P}$ amounts in shoots with increasing external $\mathrm{P}$ supplies as a reason of increasing $P$ concentrations and biomass when P supply was improved. Although safflower was reported as an inferior species compared to sunflower in terms of
$P$ accumulation in a pot experiment [14], and in nutrient solution experiment [13], both species were found similar in this study when they were grown in loamy soil at very low P supply, but sunflower was superior as compared to safflower at high $\mathrm{P}$ supply in loamy soil and at both low and high $\mathrm{P}$ supplies in sandy soil (Fig. 3). Because safflower and sunflower differ in vegetative size, both species could be compared in terms of the relative $\mathrm{P}$ accumulation, thus safflower was found superior as compared to sunflower in terms of the relative $\mathrm{P}$ accumulation in shoots in low and intermediate $\mathrm{P}$ supply in sandy soil (46.8 and $64.1 \%$ in safflower as compared to 27.2 and $30.4 \%$ for sunflower at 0 and $0.2 \mathrm{~g} \mathrm{pot}^{-1}$ respectively) and at low $\mathrm{P}$ supply in loamy soil types (24.7\% for safflower as compared to $20.0 \%$ for sunflower at 0 added $\mathrm{P}$ pot $^{-1}$ ). The increased plant biomass of sunflower plants as compared to safflower may results in a dilution effect of nutrient content in dry matter of sunflower [42,43]. In previous reports, safflower was found more efficient than sunflower in terms of $\mathrm{N}[9,10]$ accumulation.

\section{3. $P$ Use Efficiency}

Different species and cultivars within a species vary widely in their ability to thrive in nutrient- deficient environments, and therefore differ greatly in their nutrient efficiencies [7]. These genotypic differences are related to differences in efficiency of acquisition by the roots or in nutrient utilization by the plant, or both [6]. Different concepts of nutrient efficiency have been developed, some giving emphasis to productivity and others to internal nutrient requirement [17], and in some cases their interpretations are misleading [6,9]. To characterize different plant species or genotypes for NUE, researchers use many criteria, including the presence or absence of deficiency symptoms [44], absolute growth at a limiting nutrient level [45], relative growth obtained by comparing growth at limiting and adequate nutrient levels [46], efficiency ratio (ER) or amount of biomass produced per unit of nutrient present in the tissues [47], the use of yield response curves in terms of the functional relationship between yield and nutrient accumulated in the aboveground biomass, or nutrient supply in nutrient media using Michaelis-Menten-type equation [9,10,11,13], and utilization coefficient as the inverse of the whole plant nutrient concentration being expressed on a dry matter basis [13]. The plants nutrient efficiency could be also assessed by other terms like the "external" and "internal" P requirements for plant growth and yield under limited nutrient availability in soil. The internal requirement is the minimum uptake by a plant associated with a specific yield, usually near maximum growth [20]. It is also defined as the critical concentration for optimal crop growth or yield i.e. the nutrient concentration in plants sufficient to produce a certain proportion, e.g. $90 \%$, of maximum dry matter yield [14]. Therefore, plants growing under limited P conditions with a low internal $\mathrm{P}$ requirement may have a low external $P$ requirement or may be inefficient in acquiring nutrient, but they must be efficient in using the nutrient taken up to produce dry matter. The external nutrient requirement of plants is the nutrient concentration in soil solution associated with adequate nutrition or growth [20]. 
As a convenient mean of expressing $\mathrm{P}$ utilization efficiency in this study, nutrient accumulation, efficiency ratio (ER), utilization index (UI), agronomic efficiency, and $\mathrm{P}$ recovery were used. For these utilization efficiency parameters, both species under study were previously evaluated in terms of nitrogen [11], phosphorous [13,14], and potassium [10], in a soil-sand-perlite growth media, while two soil types was used in this study and soil parameters were investigated $[\mathrm{P}$ capacity (CAL-P) and $\mathrm{P}$ intensity (soil solution-P)].

\subsubsection{P Efficiency Ratio (PER)}

Efficiency ratio (Figure $4 \mathrm{~A}$ and $\mathrm{B}$ ), defined as the biomass production per unit nutrient accumulated, is widely used as an efficiency indicator comparing alternative crops grown under moderate to severe nutrient deficiency [28]. It is a valuable parameter in differentiating plants into efficient and inefficient utilizers of the absorbed nutrients [21], and has been used extensively to describe internal nutrient requirements in many agronomic species [17]. The continuously increasing values of PER of both crops to produce DM yield (Fig. 4 A and B), in response to decreasing nutrient supply, represents the general response of the adaptation of different species to nutrient-poor environments by enhancing their nutrient utilization efficiency [1]. Similar observations have been reported $[10,11,13,14]$. However, the ability of safflower grown in sandy soil to utilize $\mathrm{P}$ more efficiently than sunflower at low and high low $\mathrm{P}$ supplies indicates that safflower is good responsive in increasing their utilization efficiency in sandy soils in poor P status. Additionally, in loamy soil, safflower and sunflower had similar efficiency ratios at intermediate $\mathrm{P}$ supply, safflower had higher PER at high $\mathrm{P}$ supply indicating that safflower is better in utilizing $\mathrm{P}$ as compared to sunflower at high P supply in loamy soils.

\subsubsection{P utilization Index (UI)}

The utilization index [10,11,29] is an efficiency parameter defined as biomass produced per unit of tissue nutrient concentration. Unlike the efficiency ratio, UI takes differences in the amount of produced biomass into consideration. UI was proposed [29] to avoid the interpretation of the dilution effect under low nutrient supply as utilization efficiency when interpreted in terms of ER $[10,11]$. In agreement with previous published work $[13,14]$, the data of this study in terms of $\mathrm{P}$ utilization index support the superiority of sunflower over safflower at all respective $\mathrm{P}$ supplies including high and low $\mathrm{P}$ levels (Figure $4 \mathrm{C}$ and D) in both soil types. Results of UI indicate that the high values of efficiency ratios (PER in Figure $4 \mathrm{~A}$ and $\mathrm{B}$ ) obtained at very low $\mathrm{P}$ levels could be a reason of dilution effect of $\mathrm{P}$ rather than an actual efficiency in $\mathrm{P}$ utilization when $\mathrm{P}$ is very limiting because $\mathrm{P}$ concentration in the biomass tends to decrease.

\subsubsection{External $P$ Requirement}

An agronomic definition of nutrient efficiency relates plant productivity to nutrient supply [27]. Nutrient efficiency has also been calculated on the basis of the external amount of nutrient available [28]. The term "external nutrient requirement" refers to the amount of nutrient in the media required to produce a given percentage of maximum yield [19]. According to all these interpretations for nutrient use efficiency, a calculation was adopted that defines the required external nutrient quantity in different forms (soil solution P, extractable P, and finally P supply) to produce $1 \mathrm{~kg}$ of DM. Safflower's agronomic $\mathrm{P}$ requirement in terms of external $\mathrm{P}$ supplies, extractable $\mathrm{P}$, and soil solution $\mathrm{P}$ was higher than that of sunflower at all respective $P$ levels, which indicates the less efficiency of safflower as compared to sunflower (Table 1).

\subsection{4. $P$ recovery}

Phosphorous recovery percentage (efficiency) rarely exceeds $25 \%$ from added P [48] in the first year. If only $25 \%$ of the $\mathrm{P}$ in a crop has come from the freshly applied fertilizer, the remaining $75 \%$ must have come from soil reserves of $\mathrm{P}$. Therefore, if soil $\mathrm{P}$ fertility is to be maintained, any $\mathrm{P}$ from the soil reserves must be replaced. So it is reasonable to consider that the source of total $\mathrm{P}$ in a crop comes part from the fertilizer, and part from soil reserves (maintained by fertilizer $\mathrm{P}$ addition), which represents the long-term recovery of fertilizer $P$. Phosphorous use efficiency was calculated in this investigation according to the "Balance Method" proposed [49] and developed further [50]: percent recovery $=(\mathrm{P}$ removal by crop/ $\mathrm{P}$ applied) $\mathrm{x} 100$. In relation to the availability of soil $\mathrm{P}$ for uptake by plant roots, it was suggested that soil $\mathrm{P}$ could be considered to exist in four pools. The four pools are: soil solution $\mathrm{P}$ which is immediately available and accessible in solution, surface absorbed $\mathrm{P}$ which is readily available with high accessibility because it is readily extractable, strongly bonded $\mathrm{P}$ with low accessibility and extractability, and finally very strongly bonded $\mathrm{P}$ with very low availability $[50,51]$. Besides considering that the four pools of soil $\mathrm{P}$ were characterized by the availability of the $\mathrm{P}$ for uptake by plant roots [51], the four pools are related to the extractability of $\mathrm{P}$ by chemical reagents [50]. The amount of $\mathrm{P}$ in each of the four pools is related firstly to differences in bonding energy for $\mathrm{P}$ between binding sites on the surfaces and within soil constituents that able to retain $\mathrm{P}$ and secondly to the variations in the proportion of such sites within the soil matrix. There is reversible transfer of $\mathrm{P}$ between the soil solution, the readily plantavailable $\mathrm{P}$ pool, and the less-readily plant-available pool. Phosphorus is taken up from the soil solution by plant roots as orthophosphate ions, principally $\mathrm{H}_{2} \mathrm{PO}_{4}{ }^{-}$and to a lesser extent $\mathrm{HPO}_{4}{ }^{2-}$. If not used by a crop, the applied $\mathrm{P}$ become "fixed" in soil in forms that are no longer supply the soil solution by these ions and, therefore, this $\mathrm{P}$ become no longer available for uptake by roots [48]. Routine soil analysis for plant available $\mathrm{P}$ measures the $\mathrm{P}$ in the soil solution and the readily plant-available pool. The reversible transfer of $\mathrm{P}$ between the first three pools implies an equilibrium between $\mathrm{P}$ concentration in these pools. In agreement with our findings (Table 2), the $\mathrm{P}$ recovery decreases with increasing $\mathrm{P}$ supply in both species, and sunflower has advantage over safflower to recover more added $\mathrm{P}$ [13] in terms of $\mathrm{P}$ supply, extractable $\mathrm{P}$, and soil solution P. Furthermore, the exceeded P recovery amounts by both plants from soil solution reveals that the plants can deplete the nutrient in the soil solution many times and this nutrient is continuously supplied to the soil solution from the exchangeable pool. 
Plant roots act as a sink for soil nutrients, and it is the plant that initiates nutrient transport from soil to root by depleting $\mathrm{P}$ ions at the surface of the root cell (influx). $\mathrm{P}$ influx by roots lower the initial ion concentration of the soil solution around roots, create a concentration gradient from soil toward the root, cause diffusive flux, and disturb the equilibrium between $\mathrm{P}$ ions on the solid phase with those in the liquid phase, cause their release from soil particles into solution [52].Therefore the extension of the depleted zone and the degree of depletion is basically the result of interactions between plant and soil parameters. Superior species may have higher uptake rates per unit root and time [53], and increase diffusion towards roots by steeping the concentration gradient [54]. The high number of depletion turns from soil solution was less in sandy soil as compared to loamy soils at all P levels in both species. This can be explained by the ability of loamy soil to serve as a reservoir for $\mathrm{P}$ on their clay particles surfaces -as shown by the results of CAL-P- and these surfaces can serve as a sustained release source for available $\mathrm{P}$ (soil solution) that nourish the plant with $\mathrm{P}$ ions by being influxed by root cells.

\section{Conclusion}

Both species grown better in loamy soil as compared to sandy soil. Sunflower had less external P requirements than safflower in both soils. Safflower had higher PER than sunflower at low $\mathrm{P}$ supply in sandy soil, and less values in loamy soils. Safflower had higher UI than sunflower in both soils. Safflower recovered less external $\mathrm{P}$ (added $\mathrm{P}, \mathrm{CAL}-\mathrm{P}$, soil solution- $\mathrm{P}$ ) than sunflower in both soil types. Both species contained similar $\mathrm{P}$ concentrations in shoots at low $\mathrm{P}$ supplies. Safflower accumulated less $\mathrm{P}$ amounts in shoots than sunflower in both soils. Safflower cannot be considered a low input species as compared to sunflower in terms of P uptake and utilization efficiency.

\section{Acknowledgments}

Financial support for this study was obtained from the German Academic Exchange Service (DAAD), the Palestinian funding program for research and training "ZAMALAH”, and the Dutch ep-nuffic through NICHE-PAA 233 project. Technical support by Mrs. S. Koch in department of plant nutrition and yield physiology, George-August University, Goettingen, Germany for her generous help in plant and soil samples analysis is gratefully acknowledged.

\section{Competing Interests}

None declared.

\section{Abbreviations}

P- Phosphorous, NUE- Nutrient use efficiency, CAL- Calcium acetate lactate, DM- Dry matter,
PER- Phosphorous efficiency ratio, ER- Efficiency ratio, UI- Utilization efficiency, TDM- Total dry matter.

\section{References}

[1] Marschner, H, Mineral Nutrition of Higher Plants, $2^{\text {nd }}$ ed., Academic Press, London, 1995.

[2] Vance, C.P., Uhde-Stone, C., and Allan, D.L., "Phosphorus acquisition and use: critical adaptations by plants securing a nonrenewable resource". New Phytologist, 157, 423-457. 2003.

[3] Pachauri, R.K. and Meyer, L.A. (eds.), IPCC, Climate Change: Synthesis Report. Contribution of Working Groups I, II and III to the Fifth Assessment Report of the Intergovernmental Panel on Climate Change, IPCC, Geneva, Switzerland, 2014

[4] Lambers, H., Shane, M.W, Cramer M.D, Pearse S.J. and Veneklaas E.J. "Root Structure and Functioning for Efficient Acquisition of Phosphorus: Matching Morphological and Physiological Traits", Annals of Botany, 98. 693-713. 2006

[5] Chardon, W. and Withers, P. "Introduction to papers from the UE-COST Action 832, Quantifying the agricultural contribution to eutrophication", Journal of Plant Nutrition and Soil Science, 166. 401. 2003.

[6] Sattelmacher, B., Horst, W.J. and Becker, H.C. "Factors that contribute to genetic variation for nutrient efficiency of crops", Journal of Plant Nutrition and Soil Science, 157. 215-224. 1994.

[7] Dessougi, H., Claassen, N. and Steingrobe, B, "Potassium efficiency mechanisms of wheat, barley and sugar beet grown on a K fixing soil under controlled conditions", Journal of Plant Nutrition and Soil Science, 165. 732-737. 2002.

[8] Bhadoria, P.S., Dessougi, H., Liebersbach, H. and Claassen N, "Phosphorus uptake kinetics, size of root system and growth of maize and groundnut in solution culture", Plant and Soil, 262. 327-336. 2004.

[9] Abbadi, J., Gerendás, J. and Sattelmacher, B, "Effects of nitrogen supply on growth, yield and yield components of safflower and sunflower", Plant and Soil, 360. 167-180. 2008

[10] Gerendás, J., Abbadi, J. and Sattelmacher, B, "Potassium efficiency of safflower (Carthamus tinctorius L.) and sunflower (Helianthus annuus L.) ", Journal of Plant Nutrition and Soil Science, 171. 1-9. 2008.

[11] Abbadi, J. and Gerendás, J, "Nitrogen Use Efficiency of Safflower as compared to Sunflower", Journal of Plant Nutrition, 32(6). 929-945. 2009.

[12] Abbadi, J. and Gerendás, J, "Effects of phosphorous supply on growth and yield of safflower as compared to sunflower", Journal of Plant Nutrition, 34 (12). 1769-1787. 2011.

[13] Abbadi, J. and Gerendás, J, "Phosphorous use efficiency of Safflower and Sunflower studied in nutrient solutions", Journal of Agricultural Science and Technology A, 2. 1260-1280. 2012.

[14] Abbadi, J. and Gerendás, J, "Phosphorous use efficiency of Safflower as compared to Sunflower", Journal of Plant Nutrition, 38 (7). 1121-1142. 2015.

[15] Place, F., Meybeck, A., Colette, L., de Young, C., Gitz, V., Ehsan Dulloo, E., Hall, S., Müller, E., Nasi, R., Noble, A., Spielman, D. Steduto, P. and Wiebe, K, "Food security and sustainable resource use-what are the resource challenges to food security? " in Food Security Futures: Research Priorities for the 21st Century, Dublin, Ireland. 2013.

[16] Abbadi, J, "Importance of nutrient supply (N, P, K) for yield formation and nutrient use efficiency of safflower (Carthamus tinctorius L.) compared to sunflower (Helianthus annuus L.) including an assessment to grow safflower under north German conditions", Grauer Publisher, Beuren Stuttgart, Germany, 2007.

[17] Gourley, C.J.P., Allan, D.L. and Russelle, M.P, "Plant nutrient efficiency: A comparison of definitions and suggested improvement", Plant and Soil 158. 29-37. 1994

[18] Buso, G.S.C. and Bliss, F.A, "Variability among lettuce cultivars grown at two levels of available phosphorus", Plant and Soil, 111. 67-73. 1988

[19] Föhse, D., Claassen, N., Jungk, A, "Phosphorus efficiency of plants", Plant and Soil, 110. 101-109. 1988

[20] Fox, R.L, "External phosphorus requirements of crops", in: Dowdy, R.H., Ryan, J.A., Volk, V.V. Baker, D.E. (Eds.), 
Chemistry in the Soil Environment, Spec. Publ. No. 40, American Society of Agronomy and Soil Society of America, Madison. 223239. 1981

[21] Baligar, V.C., Elgin, J.H., Richt, W.R.J. and Fageria, N.K, "Genetic diversity for nutrient use efficiency in cultivars and exotic germplasm lines of alfalfa", in: Bassam, N., El Dambroth, M.C., Loughman, B.C. (Eds.), Genetic Aspects of Plant Mineral Nutrition, Kluwer Academic Publishers, Dordrecht. 533-538. 1990.

[22] Baligar, V. C., Fageria, N. K., He, Z, "Nutrient use efficiency in plants". Communications in Soil Science and Plant Analysis, 32. 921-950. 2001

[23] Mündel H-H, Safflower Production on the Canadian Prairies. Agriculture and Agri-Food Canada. Lethbridge Research Center, Alberta. 2004

[24] Gericke, S., Kurmies, B, "Die kolorimetrische Phosphorsäure bestimmung mit Ammonium, Vanadat, Molybdat und ihre Anwendung in der Pflanzenanalyse", Zeitschrift für Pflanzenernährung, Düngung, Bodenkunde. 59 (1952) 235-247.

[25] Adams F, "Soil solution", in Carson EW (ed) The plant root and its environment. University of Virginia, Charlottesville, 441-481. 1974.

[26] Schüller, H, "Die CAL-Methode, eine neue Methode zur Bestimmung des pflanzenverfügbaren phosphates in Böden" [The CAL method, a new method for the determination of plantavailable phosphate in soils]. Journal of Plant Nutrition and Soi Science, 123. 48-63.1969.

[27] Moll, R.H., Kamprath, E.J. and Jackson, W.A, "Analysis and interpretation of factors which contribute to efficiency of nitrogen utilization". Agronomy Journal, 74. 562-564. 1982.

[28] Gerloff, G. C. and Gabelman, W. H., "Genetic Basis of Inorganic Plant Nutrition", in Läuchli, A., Bieleski, R. L.: Encyclopedia of plant physiology New series Vol. 15B, Springer Verlag, New York, 453-480. 1983.

[29] Siddiqi, Y. and Glass, A.D.M, "Utilization index: A modified approach to the estimation and comparison of nutrient utilization efficiency in plants", Journal of Plant Nutrition. 289-302. 1981

[30] Niklas, K. J. and Enquist, B. J,"On the vegetative biomass partitioning of seed plant leaves, stems, and roots", American Naturalist. 159. 482-497. 2002.

[31] Poschlod, P., Kleyer, M., Jackel, A. K., Dannemann, A. and Tackenberg, O, "BIOPOP - a database of plant traits and Internet application for nature conservation", Folia Geobotanica. 38 263-271. 2003.

[32] Cornelissen, J.H.C., Lavorel, S., Garnier, E., Díaz, S., Buchmann, N., Gurvich, D.E., Reich P.B, ter Steege, H, Morgan, H.D., van der Heijden, M.G.A., Pausas, J.G. and Poorter, H. "A handbook of protocols for standardized and easy measurement of plant functional traits worldwide", Australian Journal of Botany. 51. 335-380. 2003.

[33] Ahmad, Z., Gill, M.A., Qureshi, R.H., Rehman, H., and Mahmood, $\mathrm{T}$, "Phosphorus nutrition of cotton cultivars under deficient and adequate levels in solution culture", Communications in Soil Science and Plant Analysis, 32. 171-187. 2001.

[34] Gill, M.A., Mansoor, S., Aziz, T., Rahmatullah, and Akhtar, M.S, "Differential growth response and phosphorus utilization efficiency of rice genotypes", Pakistan Journal of Agricultural Sciences, 39. 83-87. 2002.

[35] Liao, M.T., Hocking, P., Dong, B., Delhaize, E., and Ryan, P.R, "Screening for genotypic variation in phosphorus uptake efficiency in cereals on Australian soils", in 4th International Congress, Soil Science. 2004.
[36] Gill, M.A., Sabir, M., Ashraf, S., Rahmatullah, and Aziz, T, "Effect of P-stress on growth, phosphorus uptake and utilization efficiency of different cotton cultivars", Pakistan Journal of Agricultural Sciences, 42. 42-47. 2005.

[37] Colomb, B., Debaeke, P. Jouany, C. and Nolot. J.M, "Phosphorus management in low input stockless cropping systems: Crop and soil responses to contrasting $\mathrm{P}$ regimes in a 36-year experiment in southern France", European Journal of Agronomy, 26. 154-165. 2007.

[38] Rao, I.M. and Terry. N, "Leaf phosphate status, photosynthesis, and carbon partitioning in sugar beet. IV. Changes with time following increased supply of phosphate to low-phosphate plants", Plant Physiology, 107, 1313-1321. 1995.

[39] Rao, I.M. "The role of phosphorus in photosynthesis", in: Pessarakli, M. (eds) Handbook of Photosynthesis, Marcel Dekker, New York:, 173-194. 1996.

[40] Mollier A. and Pellerin S, "Maize root system growth and development as influenced by phosphorus deficiency", Journal of Experimental Botany, 50. 487-497. 1999.

[41] Akhtar, M.S., Oki, Y. and Adachi, T, "Genetic Diversity in Brassica Cultivars under Deficiently Buffered P-Stress Environment: I. Biomass Accumulation, P-Concentration, PUptake, and Related Growth Parameters", Journal of American Science, 3(2). 55-63. 2007.

[42] Bélanger G., Claessens $\mathrm{A}$. and Ziadi N, "Grain $\mathrm{N}$ and $\mathrm{P}$ relationships in maize", Field Crops Research, 126. 1-7. 2012.

[43] Zhang H.Y., Wu, H.H., Yu, Q., Wang. Z.W., Wei, C.Z., Long, M., Kattge, J., Smith, M. and Han X, "Sampling date, leaf age and root size: implications for the study of plant C:N:P stoichiometry", Plos One, 8(4). 2013.

[44] Diers, B.W. and Fehr, W.R, "Selection for iron efficiency of soybean in nutrient solution and field tests", Crop Science, 29, 86-89. 1989.

[45] Chisholm, R.H. and Blair, G.J, "Phosphorous efficiency in pasture species based on total dry weight and P content", Australian Journal of Agricultural Research, 39. 807-816. 1988.

[46] Gerloff, G.C. "Intact-plant screening for tolerance to nutrientdeficiency stress", Plant and Soil, 99. 3-16. 1987.

[47] Coltman, R.R.., Gerloff, G.C. and Gabelman, W.H. "Differential tolerance of tomato strains to maintained and deficient levels of phosphorus", Journal of the American Society for Horticultural Science, 110. 140-144. 1985.

[48] Johnston, A.E. and Keith Syers J.K. "A New Approach to Assessing Phosphorus Use Efficiency in Agriculture", Better Crops, 93 (3) 2009.

[49] Johnston, A.E. and Poulton. P.R.. Rothamsted Experimental Station Report for 1976, Part 2. 53-85. 1977.

[50] Syers, J.K., Johnston, A.E. and Curtin. D. "Efficiency of soil and fertilizer phosphorus use". FAO Fertilizer and Plant Nutrition Bulletin 18. Rome, Italy. 2008.

[51] Johnston, A.E.. "Principles of crop nutrition for sustainable food production", Proceedings, 459., International Fertilizer Society., York, UK., 2001.

[52] Jungk, A. and Claassen, N, "Ion diffusion in the soil-root system", Advanced Agronomy, 61. 53-110. 1997.

[53] Steingrobe, B. and Claassen, N. "Potassium dynamics in the rhizosphere and K efficiency of crops", Journal of Plant Nutrition and Soil Science, 163. 101-106. 2000.

[54] Trehan, S.P. "Mechanism of high nitrogen efficiency in potato cultivars". Advanced Horticultural Science, 23(3). 179-84. 2009. 